\title{
PENYULUHAN PEMBELAJARAN MENULIS PUISI BERBASIS KARAKTER DI SMK PROFITA KOTA BANDUNG TAHUN AJARAN 2019-2020
}

\author{
Heri Isnaini ${ }^{1}$, Yulia Herliani ${ }^{2}$ \\ ${ }^{1}$ Pendidikan Bahasa Indonesia, Fakultas Pendidikan Bahasa, IKIP Siliwangi, Cimahi, Jawa Barat \\ e-mail: heriisnaini1985@gmail.com \\ ${ }^{2}$ SMK Profita Bandung, Jawa Barat \\ e-mail: yuliaherliani986@gmail.com
}

\begin{abstract}
Abstrak
Penyuluhan ini dilaksanakan di SMK Profita kota Bandung semester ganjil tahun ajaran 20192020. Penyuluhan ini dimaksudkan dalam rangka membina para siswa untuk memiliki karakter yang baik dengan diwujudkan dalam penulisan puisi. Penulisan puisi tersebut menjadi rekonstruksi hasil pengamatan siswa berdasarkan pembelajaran karakter yang sudah dilakukan pada mata pelajaran Pendidikan Agama dan Pendidikan Kewarganegaraan. Metode yang digunakan dalam penyuluhan ini adalah metode projek based learning dengan memanfaatkan alam sekolah sebagai wujud citraan dalam memperoleh inspirasi untuk menulis puisi. Basis karakter yang muncul adalah karakter religius, disiplin, jujur, dan tenggang rasa. Nilai-nilai ini kemudian terafirmasi dalam bentuk-bentuk bait dalam puisi yang pada akhirnya dapat dibaca oleh warga sekolah dalam bentuk gerakan literasi sekolah. Produk yang dihasilkan pada penyuluhan ini adalah teks puisi siswa yang berlandasakan karakter yang memiliki nilai-nilai religius dan kemanusiaan. Pengalaman siswa dalam menulis puisi ini diharapkan dapat memupuk nilai-nilai karakter luhur yang selama ini dipahami hanya sebagai bagian dari pembelajaran mata pelajaran tertentu. Dengan demikian, penyuluhan ini menjadi tonggak dasar yang paling awal dalam mengokohkan nilai-nilai karakter religius dan sosial dalam bentuk pembelajaran menulis puisi.
\end{abstract}

Kata kunci: pembelajaran, menulis, puisi, karakter

\begin{abstract}
This counseling was held at the Profita Vocational School in Bandung in the odd semester of the 2019-2020 school year. This counseling is intended in order to foster students to have good character by embodied in poetry writing. Poetry writing is a reconstruction of student observations based on character learning that has been done in the subjects of Religious Education and Citizenship Education. The method used in this extension is a project based learning method by utilizing the nature of the school as a form of image in obtaining inspiration to write poetry. The character bases that emerge are religious, disciplined, honest, and considerate. These values are then affirmed in the form of stanzas in poetry which can ultimately be read by school members in the form of school literacy movements. The product produced in this counseling is the poetry text of students based on characters that have religious and humanitarian values. Students' experience in writing poetry is expected to be able to foster noble character values that have been understood only as part of learning certain subjects. Thus, this counseling became the earliest basic milestone in strengthening the values of religious and social character in the form of learning to write poetry.
\end{abstract}

Keywords: learning, writing, poetry, character

\section{PENDAHULUAN}

Penyuluhan ini berbasis pembelajaran kompetensi bahasa. Kompetensi yang diajarkan adalah kompetensi produktif, yakni menulis. Kompetensi bahasa sendiri terdiri atas kompetensi reseptif (menyimak dan membaca) serta kompetensi produktif (menulis dan berbicara) yang semuanya msuk ke dalam keterampilan berbahasa. Pengajaran bahasa pada hakikatnya bertujuan agar siswa 
terampil menyimak, terampil berbicara, terampil membaca, dan terampil menulis (Tarigan, 2008: $3)$.

Bahasa Indonesia sendiri adalah bahasa pengantar dalam pendidikan berdasarkan regulasi dan undang-undang tentang Bahasa Nasional dan Bahasa Negara di semua jenis jenjang pendidikan, mulai dari pendidikan dasar, menengah, atas, hingga perguruan tinggi. Peranan Bahasa Indonesia sebagai bahasa yang diupayakan meningkatkan mutu pendidikan, pengajaran, dan penguasaan bahasa baik lisan maupun tulisan terkendala faktor-faktor penghambat, yakni kesadaran akan pentingnya bahasa sebagai bagian yang penting dalam kehidupan sehari-hari.

Penyuluhan yang diadakan di SMK Profita ini adalah bagian dari upaya untuk meningkatkan kemampuan dan keterampilan berbahasa dalam bentuk keterampilan produktif, yakni keterampilan menulis. Keterampilan menulis adalah salah satu keterampilan berbahasa yang dinilai cukup sulit karena menulis harus mengedepankan pengetahuan yang sudah diterima sebanyak-banyaknya sehingga pengetahuan tersebut terinternalisasi menjadi pemahaman yang dituangkan dalam media bahasa. Menurut Dalman (2016: 3) mengungkapkan bahwa menulis merupakan suatu kegiatan komunikasi berupa menyampaikan pesan (informasi) secara tertulis kepada pihak lain dengan menggunakan bahasa tulis sebagai alat atau medianya. Selain itu, pengertian ini dipertegas oleh Tarigan (2008: 3) mengatakan bahwa menulis merupakan suatu keterampilan berbahasa yang dipergunakan untuk berkomunikasi secara tidak langsung, tidak secara tatap muka dengan orang lain. Dengan demikian, kedudukan menulis dalam pembelajaran bahasa sangat penting dan penyuluhan menjadi urgen dan harus dilaksanakan dengan terus-menerus.

Pembelajaran adalah salah satu aspek penting yang harus dikedepankan dalam penyuluhan ini. dengan demikian harus dimaknai sebagai bagian dari kehidupan manusia. Menurut Huda (2015: 2) "pembelajaran dapat dikatakan sebagai hasil dari memori, kognisi, dan metakognisi yang berpengaruh terhadapan pemahaman". Hal inilah yang terjadi ketika seseorang sedang belajar, dan kondisi ini juga sering terjadi dalam kehidupan sehari-hari, karena belajar merupakan proses alamiah setiap orang. Selanjutnya, Sagala (2019: 61) menjelaskan bahwa pembelajaran adalah upaya membelajarakan siswa menggunakan asas pendidikan maupun teori belajar yang merupakan penentu utama keberhasilan pendidikan. Simpulan dari pentingnya konsep pembelajaran ini disampaikan oleh Aunurrahman (2015: 9) yang menjelaskan bahwa pembelajaran merupakan proses transfer informasi atau transfer of knowledge dari guru kepada siswa dengan mengedepankan aspek-aspek pembentukan karakter.

Penjelasan mengenai pendidikan karakter menjadi penting karena menjadi dasar dari proses pembelajaran yang efektif dan berdaya guna. Menurut Mufarizuddin et al (2020: 30) pendidikan karakter adalah suatu sistem penanaman nilai-nilai karakter kepada warga sekolah yang meliputi komponen pengetahuan, kesadaran atau kemauan, dan tindakan untuk melaksanakan nilai-nilai tersebut. Pendidikan karakter dapat dimaknai sebagai "the deliberate use of all dimensions of school life to foster optimal character development". Konsep ini bersinggungan dengan ranah afektif yang dimaknai sebagai ranah yang berkaitan dengan sikap dan nilai. Kemampuan afektif merupakan bagian dari hasil belajar dan memiliki peran yang penting (Insani, Astuti, \& Zulfah, 2020: 1).

Pembelajaran menulis yang berkaitan dengan aspek pembentukan karakter memiliki irisan dengan penciptaan karya sastra, puisi. Karya sastra (dalam hal ini puisi) dalam pembelajaran di sekolah tercantum dalam bahan ajar yang disebut teks. Hal ini sebagaimana penjelasan yang mengatakan bahwa bahan ajar dan teks dalam mata pelajaran Bahasa Indonesia merupakan dua hal yang tidak bisa dipisahkan. Hal ini disebabkan karena basis pembelajaran Bahasa Indonesia adalah teks (Wikanengsih, Isnaini, \& Kartiwi, 2019: 54).

Teks puisi dalam pembelajaran ini mengakomodasi tema-tema pembentukan karakter karena puisi mengandung unsur imajinasi yang dapat membentuk karakter kuat, misalnya: kesadaran akan ketuhanan. Proses kesadaran ini terdapat dalam simbol-simbol dalam puisi itu sendiri. Hal ini disebabkan dalam kajiannya hanya melihat tanda sebagai bahan kajian dan dalam sebuah tanda secara implisit (Isnaini, 2018: 2). Piranti tanda dan simbol ini digunakan fokus pada pemaknaan ikon, indeks, dan simbol sesuai dengan trikotomi Pierce dengan memperhatikan hubungannya dengan teks-teks lain .(Isnaini, Priyatna, Rahayu, \& Adji, 2019: 117). Secara etimologi istilah puisi berasal dari bahasa Yunani poeima "membuat" atau poeisis "pembuatan", dan dalam bahasa inggris disebut poem atau poetry (Aminuddin, 1995: 134). Mengutip pendapat Mc Caulay Hudson 
(Aminuddin, 1995: 135) mengungkapkan bahwa puisi adalah salah satu cabang sastra yang menggunakan kata-kata sebagai media penyampaian untuk membuahkan ilusi dan imajinasi.

Berdasarkan penjelasan di atas, penyuluhan pembelajaran menulis puisi berbasis karakter ini menggunakan konsep project based learning. Konsep ini menjadi penting dalam rangka membentuk karakter tanggung jawab dan disiplin siswa dalam memahami dan mengaplikasikan teori menulis puisi yang sudah dijelaskan dalam penyuluhan. Seperti yang dijelaskan oleh Oakey (1998: 14) bahwa konsep dan karakteristik project-based learning dengan membedakannya dengan problem based learning yang seringkali saling dipertukarkan dalam penggunaan istilah ini. Istilah project based learning dan problem based learning masing-masing digunakan untuk menyatakan strategi pembelajaran. Dengan demikian, urgensi dari penyuluhan ini menjadi tidak terbantahkan. Mudah-mudahan dengan penyuluhan ini, pembelajaran menulis puisi berbasis karakter ini menjadi bermanfaat dan dapat dikembangkan lebih komprehensif dan progresif.

\section{METODE}

Metode yang digunakan penulis dalam penyuluhan ini adalah deskriptif. Penjelasan yang dikemukakan Moleong (2002: 20) bahwa metode ini penulis berusaha untuk mengumpulkan masalah aktual, Menyusun, dan mengklasifikasikan data dengan langkah-langkah yang ditempuh. Secara teoretis, Suharsimi (2006: 5) menjelaskan bahwa metode adalah cara-cara utama yang digunakan dalam mencapai satu tujuan. Siapa pun, dari bidang mana pun, orang membutuhkan penelitian untuk meningkatkan usaha yang dilakukannya.

Pada penyuluhan ini penyuluhan dilaksanakan dengan Langkah-langkah berikut: (1) pengumpulan data dengan observasi dan pengamatan langsung; (2) persiapan mengajar yang terdiri atas persiapan silabus dan teknik pembelajaran; (3) pelaksanaan penyuluhan dengan proses pembelajaran di kelas (pelaksanaan kegiatan belajar mengajar); dan (4) Hasil penyuluhan/hasil pembelajaran.

\section{HASIL DAN PEMBAHASAN}

Hasil dan pembahasan dari kegiatan penyuluhan yang sudah dilaksanakan di SMK Profita kota Bandung ini dapat dijelaskan menjadi beberapa tahapan-tahapan yang sudah dikerjakan. Berikut penjelasannya:

\section{A. Deskripsi Persiapan Pembelajaran Menulis Puisi}

Persiapan pembelajaran merupakan hal yang sangat penting. Dalam setiap pembelajaran aspek persiapan atau (plan) terdiri atas:

1. memepersiapkan materi sesuai silabus yang digunakan

2. menentukan Kompetensi Inti (KI) dan Kompetensi Dasar (KD)

3. merumuskan indikator dari KI dan KD

4. menyesuaikan KI, KD, Indikator pembelajaran dengan tingkatan kelas

5. menentukan model dan strategi pembelajaran

6. menuliskan tahap persiapan ini dengan Rencana Pelaksanaan Pembelajaran

\section{B. Deskripsi Model Pelaksanaan Pembelajaran Menulis Puisi}

Pelaksanaan pembelajaran menulis puisi bebas harus sesuai dengan tahapan persiapan pembelajaran yang sudah disusun sebelumnya. Pada kegiatan ini, yang dilakukan adalah pelaksanaan pembelajaran berbasis karakter dengan tujuan akhir siswa adalah menghasilkan sebuah karya puisi (proyek). Pelaksanaan pembelajaran ini harus menyenangkan dan mengarahkan siswa menjadi memahami materi yang disampaikan. Tujuan dari pelaksanaan pembelajaran yang menyenangkan adalah:

1. menciptakan lingkungan belajar yang efektif;

2. menciptakan proses belajar yang menyenangkan;

3. menyesuaikan kemampuan otak dengan apa yang dibutuhkan oleh otak;

4. membantu meningkatkan keberhasilan hidup dan karir;

5. membantu mempercepat dalam pembelajaran.

Adapun penjelasan pelaksanaan penyuluhan pembelajaran dapat dijelaskan sebagai berikut. (A) tahap pendahuluan, yang dilakukan adalah sebagai berikut: 
1. Siswa menjawab sapaan guru, berdoa, dan mengondisikan diri siap belajar.

2. Siswa melakukan apersepsi.

3. Guru menyampaikan tujuan pembelajaran dan memberikan manfaat penjelasan tentang manfaat menguasai materi pembelajaran.

4. Guru menyampaikan pokok-pokok atau cakupan materi pembelajaran.

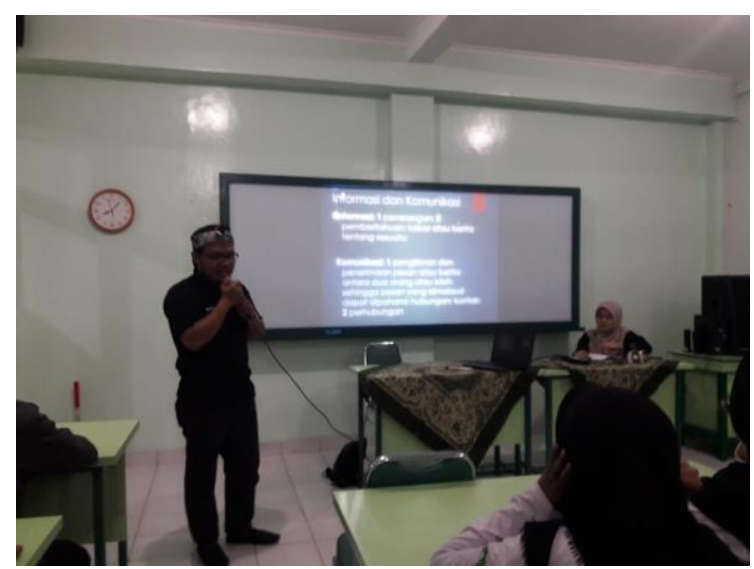

Gambar 1. Penyuluh memberikan pengarahan dalam rangka pembelajaran menulis puisi

Pada tahapan ini ada nilai karakter yang muncul, yaitu: religius, rasa ingin tahu, bersahabat, dan komunikatif. (B) tahap inti, kegiatan yang dilakukan adalah:

1. Guru mengajukan pertanyaan kepada siswa tentang pengetahuan awalnya mengenai puisi.

2. Siswa menjawab pertanyaan-pertanyaan yang diajukan oleh guru.

3. Guru memutar rekaman cerita atau lagu atau musik instrumental, untuk membangkitkan imajinasi siswa

4. Siswa mengamati rekaman yang diputar.

5. Guru menjelaskan materi penulisan puisi sesuai dengan konsep dan teori

6. Siswa dan guru bertanya jawab tentang langkah-langkah menulis puisi

7. Siswa menulis puisi sesuai dengan Langkah-langkah yang sudah dijelaskan

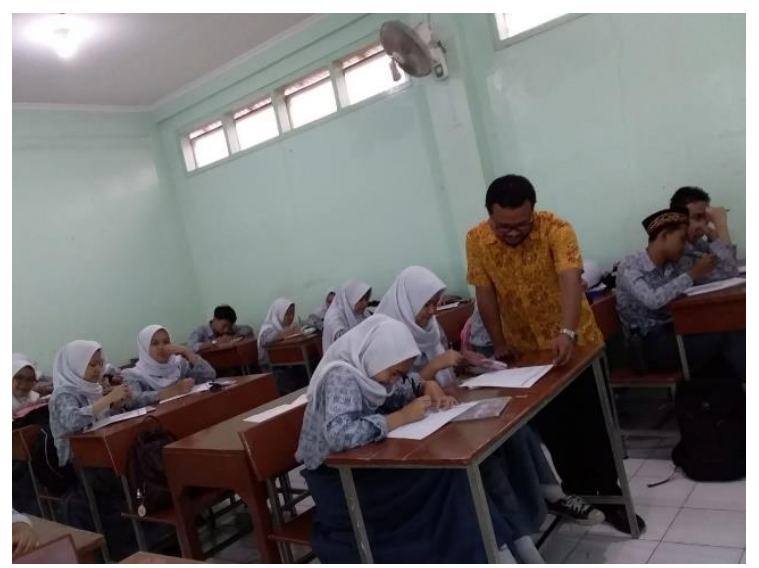

Gambar 2. Memberikan pelatihan menulis puisi

Pada tahapan ini ada nilai karakter yang muncul, yaitu: berani, tanggung jawab, disiplin, rasa ingin tahu, bersahabat, dan komunikatif. (C) tahap penutup, kegiatan yang dilakukan adalah:

1. Guru dan siswa bersama-sama menyimpulkan materi pembelajaran yang telah dipelajari.

2. Guru dan siswa melakukan refleksi terhadap kegiatan yang telah dilakukan.

3. Guru dan siswa merencanakan tindak lanjut pembelajaran untuk pertemuan selanjutnya.

4. Pembelajaran diakhiri dengan doa dan salam 

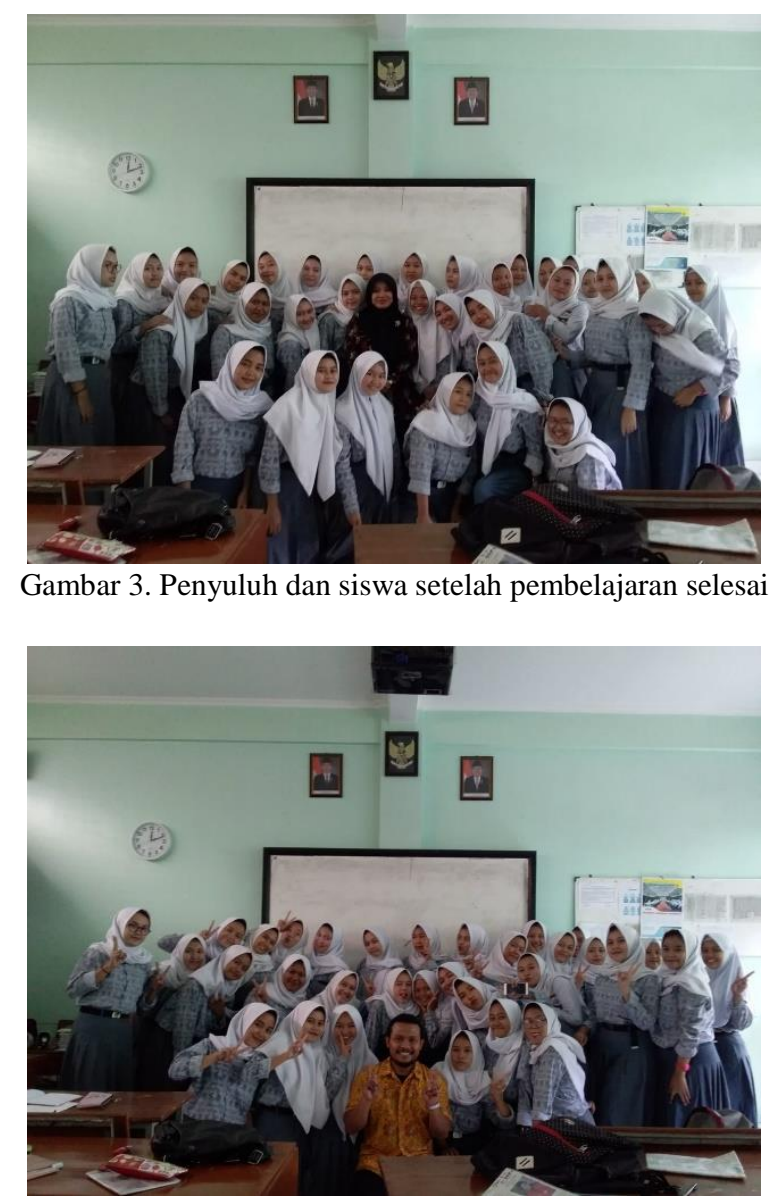

Gambar 4. Penyuluh dan siswa setelah pembelajaran selesai

Pada tahapan ini ada nilai karakter yang muncul, yaitu: religius, bersahabat, dan komunikatif.

\section{Deskripsi Hasil Pelaksanaan Pembelajaran Menulis Puisi}

Hasil dari penyuluhan pembelajaran menulis puisi ini adalah tumbuhnya nilai-nilai karakter yang tumbuh dan berkembang pada diri siswa. Hal ini dapat diharapkan terwujudnya karakter dan upaya memfungsikan kedua belahan otak kiri dan otak kanan pada fungsinya masing-masing. Dengan demikian siswa dapat lebih memanfaatkan kedua kemampuannya secara seimbang (otak kiri dan kanan).

Manfaat dari penyuluhan ini diharapkan dapat meningkatkan peran sebagai siswa atau individu yang memikul tanggung jawab pada diri sendiri sehingga dapat meningkatkan kualitas hidup dengan belajar sedapat mungkin dari setiap situasi dan memanfaatkannya untuk diri sendiri dan orang lain. Di samping itu bagi guru wajib memberi keteladanan sehingga layak menjadi panutan bagi peserta didik, berbicaralah yang jujur, jadi pendengar yang baik dan selalu gembira (tersenyum). Selain itu, guru harus membuat suasana belajar yang menyenangkan/kegembiraan, learning is most effective when it is fun, kegembiraan disini berarti bangkitnya minat, adanya keterlibatan penuh, serta terciptanya makna, pemahaman (penguasaan atas materi yang dipelajari), dan nilai yang membahagiakan pada diri siswa.

\section{SIMPULAN}

Penyuluhan ini adalah program Pengabdian Pada Masyarakat yang difokuskan pada masyarakat Pendidikan. Pembelajaran menulis puisi pada siswa sekolah menjadi pokok dalam penyuluhan ini. Kegiatan yang dilakukan terbagi menjadi kegiatan plan, do, see (persiapan, pelaksanaan, dan evaluasi). Ketiga kegiatan tersebut diharapkan menjadikan siswa lebih giat belajar, khususnya dalam pembelajaran menulis puisi. Dalam hal ini, kegiatan dilaksanakan oleh 2 penyuluh, guru mata pelajaran Bahasa Indonesia sebagai ujung tombak pembelajaran dan penyuluh sendiri. Hasil 
dari kegiaatan ini menunjukkan bahwa pembelajaran yang menarik sangat menentukan hasil dan pembentukan karakter siswa seperti yang diharapkan.

Dengan kata lain, kegiatan penyuluhan pembelajaran menulis puisi ini dapat meningkatkan peran guru dan siswa dalam mengembangkan karakter. Kegiatan ini pun telah memerikan sumbangan pemikiran dan pelatihan bagi siswa dalam rangka menyeimbangkan kemampuan otak kiri dan kanan. Pada penyuluhan ini penyuluhan dilaksanakan dengan Langkah-langkah berikut: (1) pengumpulan data dengan observasi dan pengamatan langsung; (2) persiapan mengajar yang terdiri atas persiapan silabus dan teknik pembelajaran; (3) pelaksanaan penyuluhan dengan proses pembelajaran di kelas (pelaksanaan kegiatan belajar mengajar); dan (4) Hasil penyuluhan/hasil pembelajaran.

\section{SARAN}

Kegiatan ini tentu saja terdapat banyak kekuarangan di berbagai segi. Hal ini tentu saja harus diperbaiki dan disempurnakan pada kegiatan selanjutnya. Misalnya, nilai-nilai karakter yang muncul harus lebih komprehensif dan sasaran sekolah harus diperluas sehingga peran guru di sekolah dan penyuluh di perguruan tinggi terlihat signifikan.

\section{UCAPAN TERIMA KASIH}

Kami mengucapkan terima kasih kepada pihak-pihak yang membantu dalam kegiatan penyuluhan dan pemublikasian artikel ini. Beberapa pihak tersebut diantaranya: (1) Rektor IKIP Siliwangi, Dekan Fakultas Pendidikan Bahasa, dan Ketua Prodi Pendidikan Bahasa dan Sastra Indonesia; (2) Ketua Yayasan Pendidikan Ekonomi Bandung, Kepala SMK Profita Bandung, Guru, Staf TU, dan para siswa SMK Profita Bandung; (3) Pihak-pihak yang membantu penyuluhan dan pemublikasian artikel ini; (4) Kepala LPM Community Development Journal, Universitas Pahlawan Tuanku Tambusai, Bangkinang; dan (5) semua pihak yang membantu dan tidak dapat disebutkan satu persatu.

\section{DAFTAR PUSTAKA}

Aminuddin. (1995). Stilistika: Pengantar Memahami Bahasa dalam Karya Sastra. Semarang: IKIP Semarang Press.

Aunurrahman. (2015). Belajaran dan Pembelajaran. Bandung: Alfabeta.

Dalman. (2016). Keterampilan Menulis. Jakarta: Raja Grafindo Persada.

Huda, M. (2015). Model-Model Pengajaran dan Pembelajaran. Yogyakarta: Pustaka Pelajar.

Insani, S. U., Astuti, \& Zulfah. (2020). Pelatihan Pengembangan Instrumen Penilaian Teknik Non

Tes Bagi Guru MAN 4 Kampar. Communnity Development Journal, Vol.1, No. 1 Februari 2020, 1-3.

Isnaini, H. (2018). Ideologi Islam-Jawa pada Kumpulan Puisi Mantra Orang Jawa Karya Sapardi Djoko Damono. MADAH: Jurnal Balai Bahasa Riau, Badan Pengembangan dan Pembinaan Bahasa, Kemendikbud, Vol 9, No 1 (2018), 1-18.

Isnaini, H., Priyatna, A., Rahayu, L. M., \& Adji, M. (2019). Konsep Manunggaling Kawula Gusti Pada Puisi-Puisi Sapardi Djoko Damono. Jurnal Ide Bahasa, Vol. 1 No. 2 Desember 2019, 115-128.

Moleong, L. (2002). Metodologi Penelitian Kualitatif. Bandung: Remaja Rosdakarya.

Mufarizuddin, Fauziddin, M., \& Rizal, M. S. (2020). Pembelajaran Pendidikan Kewarganegaraan Berbasis Karakter Di SD 004 Bangkinang. Communnity Development Journal, Vol.1, No. 1 Februari 2020, 29-35.

Oakey, J. (1998). Project-Based and Problem-Based: Same or Different? Retrieved from http://pblmm.k12.us/PBLGuide/PBL\&PBL.html

Sagala, S. (2019). Konsep dan Makna Pembelajaran. Bandung: Alfabeta.

Suharsimi, A. (2006). Prosedur Penelitian. Jakarta: PT. Raja Grafindo Persada.

Tarigan, H. G. (2008). Menulis Sebagai Suatu Keterampilan Berbahasa. Bandung: Refika Aditama.

Wikanengsih, Isnaini, H., \& Kartiwi, Y. M. (2019). Penyuluhan Penyusunan Bahan Ajar Bahasa Indonesia yang Inovatif Bagi Guru-Guru SMP di Kabupaten Subang, Jawa Barat. Cendekia: Jurnal Pengabdian Masyarakat, Vol. 1 No. 2 2019, 51-58. 